\title{
INTERNATIONAL ORGANISATION FOR THE CAMPAIGN AGAINST TRACHOMA
}

The International Anti-Trachoma Organisation, the foundation of which had been resolved upon last year at the International Ophthalmological Congress in Amsterdam, was inaugurated in Geneva at the end of July. The sittings were held in the Palace of the League of Nations building. Twenty-one different States were represented there by forty delegates, Professor Dr. Emil de Grosz being in the chair. The session had three tasks before it: to pass the statutes, to form an Executive Committee and to decide upon the programme of the near future. The following were elected to hold office: President of the Organisation for the period of five years, Professor Emil de Grosz; Secretary General: Dr. Wibaut (Amsterdam); Secretary : Dr. Tewfik (Cairo) ; Vice-Presidents : Messrs. Angelucci (Naples), Birch-Hirschfeld (Königsberg), MacCallan (London), Marquez, Chairman of the International Ophthalmological Congress in Madrid, Morax (Paris), Park Lewis (Buffalo, U.S.A.), Szymansky, President of the Polish House; other members of the Executive Committee are: Messrs. Brandes (Antwerp), Kadlicky (Prague), De Lapersonne (Paris), Miyasnita (Tokio), and van der Hoeve (Leyden).

The representatives of the Hygienic Committee of the League of Nations: M. Lutrario, former chief of the Italian Medical Department, and M. Jitta, Chairman of the Dutch Board of Health, will join the Organisation. The representive of the "Association Internationale contre la Cécité" is to be M. De Lapersonne (Paris) and that of the International Ophthalmological Council, M. van der Hoeve (Leyden).

At the session the report of MM. Lutrario and Jitta about trachoma was distributed by the Council of the League of Nations.

The League's object is $(a)$ to further the co-operation of the various organisations for the prevention of trachoma; $(b)$ to work with the international public health organisations; (c) to follow all measures concerning the anti-trachoma campaign, to second these measures and to spread them; (d) to organise conferences to establish the scientific bases of the anti-trachoma campaign, to elucidate problems of the aetiology, diagnosis, treatment, extension and prevention of this disease, as well as the scientific and social questions therewith connected, finally to prepare the necessary legislative measures.

Messrs. Addario (Palermo) and Mayou (London) submitted demonstrations. The programme was made complete by an evening-party of the delegates, a lunch given by Professor Gourfein at his Geneva clinic, and a dinner-party arranged by M. André Patry, a Geneva 
oculist, at his French castle. Intercourse at the sittings between the delegates belonging to different nations went on in the most amicable manner. These friendly terms must be highly appreciated. Everything points to the Organisation becoming a prosperous undertaking. The countries which are obliged to prevent the disease from being introduced are indeed in the same need of a campaign against it as those where it is actually destroying eyesight. In Hungary the elements of this campaign were enacted as early as 1886 by a special law. The exertions of Japan in this respect are the object of general admiration. There are 1,000 trachoma consultation rooms, where half-a-million trachoma patients are being treated by 1,000 doctors at an annual cost of half-a-million yen.

The League of Nations has issued a special circular letter to the Governments requesting them to support the scheme.

\section{ABSTRACTS}

\section{I.-RETINA}

(I) Vogt, A. (Zurich). - The healing of retinal detachment by means of ignipuncture of the retinal tear. (Zur Heilung der Netzhautablösung mittels Ignipunktur des Netzhautrisses.) Klin. Monatsbl. f. Augenheilk., Bd. LXXXII, S. 619, 1929.

(1) A considerable amount of interest is at present being excited with regard to the treatment of detachment of the retina by ignipuncture, and a detailed paper has been published by Vogt dealing with his experiences of the method and giving what he considers contra-indications for it and an account of his rechnique. A valuable contribution was made to ophthalmology by English surgeons that conservative treatment rarely held out any hope of success in the case of retinal detachment in which there was a hole. The obvious corollary that the closure of this hole might alter the prognosis in this type of case was at the time missed, and it is to the credit of Gonin that we are in a position now to hope that, provided the hole is obliterated, this type of detachment is amenable to cure. It must not be imagined that the method outlined below is invariably successful nor that the prognosis of this disease after treatment by ignipuncture can be considered good. But the published results of Gonin and the experiences of Vogt, as detailed in the present paper, would suggest that instead of the disease being practically hopeless, there is now a fair chance of accomplishing a cure for it. 